\title{
PENERIMAAN OPINI AUDIT GOING CONCERN BERDASARKAN LEVERAGE DAN FINANCIAL DISTRESS
}

\author{
Huda Aulia Rahman \\ Universitas Mercu Buana, Jakarta \\ Jalan Meruya Selatan No.1, Kembangan, Jakarta 11650 \\ hudaauliarahman@gmail.com
}

\begin{abstract}
The purpose of this study is to determine the impact of leverage and financial distress on going concern audit opinions of mining sector companies listed on the Indonesia Stock Exchange (IDX) with the 2012-2017 research period. Leverage was proxied using debt to asset ratio (DAR), and financial distress was proxied using Altman Z-Score. The object of this research used were 17 mining sector companies selected based on the random purposive sampling method. This study used data processing logistic regression analysis using SPSS version 25 . The results of this research was financial distress have negative effect on going concern modification opinions, while leverage had no effect on going concern audit opinion.
\end{abstract}

Keywords: Financial Distress, Leverage, Going Concern Audit Opinion

\begin{abstract}
Abstrak
Penelitian ini bertujuan untuk mengetahui pengaruh leverage dan financial distress terhadap opini audit going concern perusahaan sektor pertambangan yang terdaftar di Bursa Efek Indonesia (BEI). Leverage diproksikan menggunakan debt to asset ratio (DAR) dan financial distress diproksikan menggunakan Altman Z-Score. Objek penelitian yang digunakan adalah 17 perusahaan sektor pertambangan yang dipilih berdasarkan metode random purposive sampling dengan periode penelitian 2012-2017. Penelitian ini menggunakan pengolahan data analisis regresi logistik dengan bantuan software SPSS versi 25. Hasil penelitian yang diperoleh adalah financial distress berpengaruh negatif terhadap opini audit going concern, sedangkan leverage tidak berpengaruh terhadap opini audit going concern.
\end{abstract}

Kata kunci: Financial Distress, Leverage, Opini Audit Going Concern

\section{Pendahuluan}

Tujuan berdirinya suatu perusahaan adalah memperoleh laba serta terus mempertahankan kelangsungan hidupnya. Kelangsungan hidup atau going concern adalah salah satu asumsi dasar kerangka konseptual akuntansi. Asumsi going concern menyatakan bahwa perusahaan akan terus beroperasi untuk jangka waktu yang panjang. Namun, pada kenyataannya tidak semua peruahaan memiliki kemampuan dalam mempertahankan kelangsungan usahanya. Sektor pertambangan adalah sektor yang cukup mendapat sorotan.

$$
\text { Global Mining leader }
$$

PricewaterhouseCoopers (PWC), Jock O'Callaghan (2015) dalam laman www.pwc.com mengemukakan bahwa tahun 2015 adalah tahun yang menantang bagi sektor pertambangan karena turunnya harga komoditas sebesar $25 \%$ dibandingkan dengan tahun sebelumnya. Penurunan harga komoditas mendorong perusahaan sektor pertambangan agar meningkatkan produktivitasnya, Beberapa perusahaan harus berjuang untuk dapat bertahan, disertai dengan pelepasan aset serta penutupan usaha. Lead Adviser for Energy, Utilities \& Mining PricewaterhouseCoopers (PWC), Sacha Winzenried (2015) mengungkapkan bahwa kapitalisasi pasar secara keseluruhan perusahaan sektor pertambangan yang terdaftar di Bursa Efek Indonesia (BEI) turun dari Rp 255 triliun pada 31 Desember 2014 menjadi Rp 161 triliun pada 31 Desember 2015. Penyebab penurunan sebesar $37 \%$ tersebut adalah akibat jatuhnya harga 
komoditas. Direktur Penilaian Investasi BEI Samsul Hidayat (2018) mengemukakan bahwa terdapat $10-15$ Perusahaan tercatat yang terancam delisting dari BEI lantaran perusahaan-perusahaan tersebut tidak melakukan kewajibannya dalam keterbukaan pelaporan keuangan, juga kejelasan mengenai kelangsungan usaha perusahaan tersebut.

PT Berau Coal Energy Tbk, perusahaan sektor pertambangan yang pernah menjadi primadona saat harga batu bara tinggi, resmi 'ditendang' dari Brsa Efek akibat kelangsungan hidupnya diragukan. BRAU mengalami penurunan kinerja secara drastis sejak 2013. Bahkan, pada Juli 2015 BRAU dilaporkan tidak mampu melunasi utangnya sebesar $\$ 450.000 .000$ yang telah jatuh tempo kala itu. Kelangsungan usaha BRAU semakin tidak jelas akibat perusahaan tidak menyampaikan laporan keuangannya pada semester I-tahun 2015. BEI menindaklanjutinya dengan memberikan hukuman suspensi terhadap saham BRAU pada 30 Oktober 2015. Puncaknya, pada 16 November 2017 saham BRAU resmi delisting dari lantai bursa (https://finance.detik.com/).

Going concern berkaitan dengan usaha manajemen dalam mengelola perusahaan, salah satu cara yang dapat dilakukan manajemen adalah meningkatkan kredibilitas laporan keuangan agar dapat digunakan sesuai dengan ekspektasi para penggunanya baik pemegang saham, kreditor, pemerintah, serta masyarakat (Murni dan Majid, 2017). Auditor independen diperlukan untuk memberikan opini atas kewajaran laporan keuangan perusahaan. Auditor bertanggung jawab untuk memperoleh bukti audit yang cukup serta tepat mengenai penggunaan asumsi kelangsungan usaha dalam penyusunan dan penyajian laporan keuangan perusahaan (Standar Audit seksi 570, 2013).

Rasio keuangan utama yang buruk dan ketidakmampuan perusahaan melunasi kewajibannya pada tanggal jatuh tempo merupakan kondisi yang dapat menimbulkan keraguan signifikan mengenai kelangsungan usaha perusahaan tersebut (Standar Audit seksi 570, 2013). Leverage merupakan salah satu faktor yang juga mempengaruhi penerimaan opini going concern. Rasio leverage merupakan rasio yang digunakan untuk melihat kemampuan perusahaan dalam memenuhi kewajibannya. Rasio leverage yang tinggi menandakan perusahaan banyak berutang dalam menjalankan usahanya. Besarnya proporsi utang perusahaan apabila tidak diimbangi dengan laba yang diperoleh dapat menyebabkan keraguan terhadap kelangsungan hidup perusahaan tersebut. Perusahaan yang memiliki aset yang cukup untuk membiayai semua kewajibannya disebut sebagai perusahaan yang solvable, sedangkan perusahaan yang tidak memiliki aset yang cukup untuk memenuhi kewajibannya disebut perusahaan yang insolvable (Yuliyani dan Erawati, 2017).

Financial distress merupakan faktor berikutnya yang kemungkinan memiliki pengaruh terhadap kelangsungan hidup perusahaan. Financial distress merupakan masalah keuangan yang dialami suatu perusahaan sebelum perusahaan tersebut mengalami kebangkrutan atau likuidasi (Platt dan Platt, 2006). Financial distress merupakan suatu kondisi ketika perusahaan memiliki utang yang lebih besar daripada ukuran perusahaan, profitabilitas, dan komposisi aset yang dapat dipertahankan. Menurunnya kemampuan perusahaan untuk menghasilkan pendapatan ditambah dengan arus kas operasi yang tidak memadai membuat perusahaan yang mengalami kesulitan keuangan terjebak dalam masalah likuiditas yang parah, sehingga mempengaruhi solvabilitasnya (Lin, et al, 2008).

Penelitian mengenai faktor-faktor yang mempengaruhi penerimaan opini audit going concern telah beberapa kali dilakukan sebelumnya dan menghasilkan kesimpulan yang berbeda-beda. Penelitian ini bertujuan untuk menguji ulang dan memperbarui beberapa hasil penelitian yang sudah dilakukan sebelumnya. Variabel independen yang digunakan adalah leverage dan financial distress sedangkan variabel dependen yang digunakan adalah opini audit going concern. Perbedaan penelitian ini dengan penelitian terdahulu yaitu objek penelitian dan periode penelitian. Objek penelitian yang digunakan adalah perusahaan sektor pertambangan yang terdaftar di BEI dengan periode penelitian 2012-2017. 


\section{Pengaruh Leverage terhadap Opini Audit Going Concern}

Semakin besar utang yang ditanggung perusahaan, maka semakin besar juga risikonya bagi perusahaan dalam melunasi kewajibannya. Leverage adalah peningkatan risiko dan pengembalian melalui pembiayaan biaya tetap, seperti utang dan saham preferen (Gitman dan Zutter, 2012). Yuliyani dan Erawati (2017) mengemukakan bahwa perusahaan dengan aset yang cukup untuk membiayai seluruh kewajibannya disebut sebagai perusahaan yang solvable, sedangkan perusahaan yang tidak memiliki aset yang cukup untuk memenuhi kewajibannya disebut perusahaan yang insolvable.

Penelitian yang dilakukan Santoso dan Wiyono (2013) memperoleh hasil bahwa leverage yang diproksikan debt to asset ratio berpengaruh positif terhadap penerimaan opini audit going concern. Penelitian yang dilakukan oleh Aryantika dan Rasmini (2015) juga menghasilkan kesimpulan yang serupa yaitu leverage yang diproksikan debt to asset ratio memiliki pengaruh positif terhadap penerimaan opini audit going concern. Hasil yang sama juga diperoleh Lie, et al (2016), dan Anita (2017) yaitu leverage yang diproksikan debt to asset ratio berpengaruh positif terhadap penerimaan opini audit going concern.

Hipotesis yang terbentuk berdasarkan uraian tersebut yaitu:

\section{$\mathrm{H}_{1}$ : Leverage berpengaruh positif terhadap opini audit going concern.}

\section{Pengaruh Financial Distress terhadap Opini Audit Going Concern}

Financial distress merupakan masalah keuangan yang dialami suatu perusahaan sebelum perusahaan tersebut mengalami kebangkrutan atau likuidasi. Hampir semua proses kebangkrutan diawali dengan financial distress kecuali bangkrutnya perusahaan yang disebabkan oleh kejadian yang terjadi tiba-tiba atau tidak terduga seperti bencana alam, perubahan peraturan pemerintah, serta penilaian hukum (Platt dan Platt, 2006).

Penelitian yang dilakukan oleh Ibrahim dan Raharja (2014) menghasilkan kesimpulan bahwa financial distress yang diproksikan model Altman Z-Score berpengaruh negatif terhadap penerimaan opini going concern. Penelitian yang dilakukan oleh Muhamadiyah (2013), Yuliyani dan Erawati (2017), Rahim (2017), serta Jamaluddin (2018) juga memperoleh hasil bahwa financial distress yang diproksikan model Altman Z-Score berpengaruh negatif terhadap penerimaan opini going concern.

Hipotesis yang terbentuk berdasarkan uraian tersebut yaitu:

\section{$\mathrm{H}_{2}$ : Financial Distress berpengaruh negatif terhadap opini audit going concern.}

\section{Metode Penelitian}

Penelitian ini dilakukan berdasarkan data laporan keuangan audited perusahaan go public yang diperoleh dari situs resmi Bursa Efek Indonesia (http://www.idx.co.id). Objek penelitian yang digunakan adalah perusahaan sektor pertambangan yang terdaftar di BEI periode $2012-2017$

Objek penelitian dipilih menggunakan teknik random purposive sampling dengan kriteria: 1) Perusahaan Perusahaan sektor pertambangan yang terdaftar di BEI periode 2012-2017; 2) Perusahaan yang melakukan initial public offering (IPO) sebelum tahun 2012; 3) Perusahaan yang mengalami kerugian minimal 2 (dua) kali pada rentang tahun 20122017; dan 4) Perusahaan yang menyediakan data keuangan secara lengkap.

Metode analisis data yang digunakan dalam penelitian ini yaitu metode kuantitatif. Teknik analisis yang digunakan untuk menguji hipotesis yaitu analisis regresi logistik menggunakan software SPSS versi 25. Analisis regresi logistik tidak memerlukan uji normalitas data pada variabel independennya (Ghozali, 2018).

Persamaan regresi logistik dalam penelitian ini adalah sebagai berikut:

$$
\operatorname{Ln} \frac{\mathrm{P}}{1-\mathrm{P}}=\alpha \beta 2 \mathrm{DAR}+\beta 3 \mathrm{ZScore}+\varepsilon
$$

Keterangan:

OGC = Opini Audit Going Concern

$\mathrm{a} \quad=$ Konstanta

DAR = Debt to Asset Ratio

ZScore $=$ Model Prediksi Kebangkrutan

Altman Z-Score

$\varepsilon \quad=$ Residual Value 


\section{Hasil dan Pembahasan}

Uji statistik deskriptif berfungsi mendeskripsikan suatu data yang dilihat berdasarkan nilai minimum, nilai maksimum, nilai rata-rata, serta standar deviasi (Ghozali, 2018).

Hasil uji statistik deskriptif dalam penelitian ini adalah sebagai berikut.

Tabel 1 Hasil Uji Statistik Deskriptif

\begin{tabular}{cc|c|c|c|c}
\hline \multicolumn{6}{c}{ Descriptive Statistics } \\
\hline & N & Minimum & Maximum & Mean & $\begin{array}{c}\text { Std. } \\
\text { Deviation }\end{array}$ \\
\hline DAR & 102 &, 00742 & 1,98553 &, 6586848 &, 39345311 \\
\hline Z-Score & 102 & $-5,50014$ & 74,95606 & 2,6088757 & 8,70572376 \\
\hline $\begin{array}{l}\text { Valid N } \\
\text { (listwise) }\end{array}$ & 102 & & & & \\
\hline
\end{tabular}

Sumber: Hasil Pengolahan Data (2019)

Tabel 1 menunjukkan bahwa variabel debt to asset ratio (DAR) memiliki nilai ratarata sebesar 0,6587 atau $65,87 \%$. Hal ini mengindikasikan bahwa rata-rata aset perusahaan pertambangan sebesar $65,87 \%$ dibiayai oleh utang. Variabel DAR memiliki nilai minimum 0,00742 dan nilai maksimum 1,98553. Sampel dengan nilai DAR terendah adalah perusahaan dengan kode saham CKRA pada tahun 2013, sedangkan yang tertinggi adalah perusahaan dengan kode saham BORN pada tahun 2015.

Variabel Z-Score memiliki nilai rata-rata sebesar 2,.6089 Hal ini mengindikasikan bahwa rata-rata perusahaan pertambangan berada pada kondisi grey area. Nilai minimum variabel $Z$-Score adalah -5,50014 dan nilai maksimum 74,95606. Sampel dengan $Z$-Score terendah adalah perusahaan dengan kode saham BORN pada tahun 2015, Sedangkan sampel dengan $Z$-Score tertinggi adalah perusahaan dengan kode saham CKRA pada tahun 2013.

Tabel 2

Hasil Uji Distribusi Frekuensi Opini Going

Concern

Opini Going Concern

\begin{tabular}{c|r|r|r|r}
\hline & & & Valid & Cumulative \\
& Frequency & Percent & Percent & Percent \\
\hline Valid 0 & 60 & 58,8 & 58,8 & 58,8 \\
\cline { 2 - 6 } & 42 & 41,2 & 41,2 & 100,0 \\
\hline Total & 102 & 100,0 & 100,0 & \\
\hline
\end{tabular}

Variabel opini going concern merupakan variabel dummy dengan keterangan apabila perusahaan memperoleh opini going concern maka diberi nilai 1 , sedangkan perusahaan yang tidak memperoleh opini going concern maka diberi nilai 0 . Tabel 4 menunjukkan bahwa sampel yang tidak memperoleh opini going concern adalah sejumlah 30 atau 58,8\%, sedangkan sejumlah 42 sampel atau $42,2 \%$ dari keseluruhan sampel memperoleh opini going concern.

\section{Hasil Uji Analisis Regresi Logistik}

Regresi logistik digunakan untuk menguji pengaruh leverage dan financial distress terhadap opini audit going concern. Regresi logistik digunakan karena variabel dependen dalam penelitian ini diproksikan menggunakan variabel dummy. Pengujian hipotesis dilakukan pada tingkat signifikansi (a) $5 \%$.

\section{Hasil Uji Kesesuaian Keseluruhan Model (Overall Model Fit)}

Uji kesesuaian keseluruhan model dilakukan untuk mengetahui apakah model telah fit dengan data saat sebelum dan sesudah variabel independen dimasukkan ke dalam model. Hasil uji kesesuaian keseluruhan model dapat dilihat pada tabel berikut.

\section{Tabel 3}

Hasil Kesesuaian Keseluruhan Model (Overall Model Fit)

\begin{tabular}{|c|c|c|c|c|c|}
\hline \multicolumn{6}{|c|}{ Iteration History ${ }^{\mathrm{a}, \mathrm{b}, \mathrm{c}, \mathrm{d}}$} \\
\hline \multirow[b]{2}{*}{ Iteration } & & \multirow[b]{2}{*}{$\begin{array}{c}-2 \text { Log } \\
\text { likelihood }\end{array}$} & \multicolumn{3}{|c|}{ Coefficients } \\
\hline & & & Constant & DAR & $\begin{array}{c}\text { Z- } \\
\text { Score }\end{array}$ \\
\hline \multirow[t]{7}{*}{ Step 1} & 1 & 126,847 & $-1,059$ & 1,191 &,- 030 \\
\hline & 2 & 123,057 &,- 788 & ,927 &,- 109 \\
\hline & 3 & 118,716 &,- 067 & 153 &,- 296 \\
\hline & 4 & 117,259 & ,381 &,- 322 &,- 466 \\
\hline & 5 & 117,155 &, 506 &,- 450 &,- 525 \\
\hline & 6 & 117,155 &, 513 &,- 457 &,- 528 \\
\hline & 7 & 117,155 &, 513 &,- 457 &,- 529 \\
\hline
\end{tabular}

a. Method: Enter

b. Constant is included in the model.

c. Initial -2 Log Likelihood: 138,209

d. Estimation terminated at iteration number 7 because parameter estimates changed by less than ,001.

Sumber: Hasil Pengolahan Data (2019)

Tabel 3 menunjukkan bahwa terjadi penurunan nilai -2 Log Likelihood yang 
awalnya sebesar 138,209 menjadi 117,155 pada nilai -2 Log Likelihood akhir. Penurunan Log Likelihood berarti bahwa model regresi dinyatakan baik atau fit dengan data.

\section{Hasil Uji Koefisien Determinasi (Nagelkerke R Square)}

Uji koefisien determinasi berfungsi untuk melihat kemampuan variabilitas variabel independen memperjelas variabilitas variabel dependen. Koefisien determinasi ditunjukkan melalui nilai Nagelkerke $R$ Square pada tabel berikut.

Tabel 4

Hasil Uji Koefisien Determinasi (Nagelkerke $R$ Square)

\begin{tabular}{lc|c|c}
\hline \multicolumn{4}{c}{ Model Summary } \\
\hline Step & $\begin{array}{c}-2 \text { Log } \\
\text { likelihood }\end{array}$ & $\begin{array}{c}\text { Cox \& Snell R } \\
\text { Square }\end{array}$ & $\begin{array}{c}\text { Nagelkerke R } \\
\text { Square }\end{array}$ \\
\hline 1 & $117,155^{\mathrm{a}}$ &, 187 &, 251 \\
\hline
\end{tabular}

a. Estimation terminated at iteration number 7 because parameter estimates changed by less than ,001.

Sumber: Hasil Pengolahan Data (2019)

Tabel 4 memperlihatkan bahwa nilai Nagelkerke $R$ Square yaitu sebesar 0,316 atau $31,6 \%$. Hasil ini menunjukkan bahwa variabilitas variabel independen berupa debt to asset ratio dan $Z$-Score mampu menjelaskan variabilitas variabel dependen sebesar $25,1 \%$, sedangkan selisihnya yaitu $74,9 \%$ dijelaskan oleh variabel lain yang tidak diteliti.

\section{Hasil Uji Kelayakan Model Regresi}

Uji kelayakan model regresi dilakukan menggunakan Hosmer and Lomeshow's Goodness of Fit Test. Hosmer and Lemesgow's Goodness of Fit digunakan untuk menguji hipotesis nol bahwa data empiris cocok/sesuai dengan model (Ghozali, 2018).

Tabel 5 Hasil Uji Kelayakan Model Regresi

\begin{tabular}{lr|rr|r}
\hline \multicolumn{4}{c}{ Hosmer and Lemeshow Test } \\
\hline Step & Chi-square & df & Sig. \\
\hline 1 & 21,566 & & 8 &, 255 \\
\hline
\end{tabular}

Sumber: Hasil Pengolahan Data (2019)

Tabel 5 menunjukkan bahwa nilai chisquare sebesar 21,566 dengan tingkat signifikansi sebesar 0,255. Nilai signifikansi sebesar 0,255 jauh melebihi kriteria Hosmer and Lemesgow's Goodness of Fit yaitu 0,05.
Hasil ini memperlihatkan bahwa nilai observasi data dapat diprediksi oleh model regresi atau model dapat diterima.

\section{Hasil Uji Matriks Klasifikasi}

Uji matriks klasifikasi berfungsi menunjukkan kekuatan prediksi model regresi. Uji matriks klasifikasi digunakan untuk memprediksi kemungkinan perusahaan menerima opini audit going concern.

Tabel 6

Hasil Uji Matriks Klasifikasi Classification Table ${ }^{\mathrm{a}}$

\begin{tabular}{|c|c|c|c|c|c|}
\hline & \multirow[b]{3}{*}{ Observed } & & \multicolumn{3}{|c|}{ Predicted } \\
\hline & & \multicolumn{3}{|c|}{$\begin{array}{l}\text { Opini Going } \\
\text { Concern }\end{array}$} & \multirow{2}{*}{$\begin{array}{l}\text { Percentage } \\
\text { Correct }\end{array}$} \\
\hline & & & 0 & 1 & \\
\hline Step & Opini Going & 0 & 53 & 7 & 88,3 \\
\hline 1 & $\begin{array}{l}\text { Concern } \\
\text { Overall } \\
\text { Percentage }\end{array}$ & 1 & 17 & 25 & $\begin{array}{l}59,5 \\
76,5\end{array}$ \\
\hline
\end{tabular}

a. The cut value is , 500

Sumber: Hasil Pengolahan Data (2019)

Tabel 6 menunjukkan kekuatan prediksi dari model regresi untuk memprediksi sampel yang memperoleh opini going concern. Sampel yang tidak memperoleh opini going concern adalah sebanyak 60 sampel. Hasil prediksi yang diperoleh adalah 53 sampel tidak memperoleh opini going concern, sedangkan 7 sampel memperoleh opini going concern. Hasil tersebut menunjukkan bahwa terdapat 53 prediksi yang tepat atau ketepatan prediksi adalah $88,3 \%$.

Sampel yang memperoleh opini going concern adalah sebanyak 42 sampel. Hasil yang diperoleh adalah 17 perusahaan memperoleh opini going concern, sedangkan 25 sampel sisanya tidak memperoleh opini going concern. Hasil tersebut menunjukkan bahwa terdapat 25 prediksi yang tepat atau ketepatan prediksi adalah 59,5\%. Ketepatan prediksi secara keseluruhan (overall percentage) dalam model regresi ini adalah $76,5 \%$.

\section{Pengujian Hipotesis}

Pengujian hipotesis bertujuan untuk mengetahui pengaruh variabel independen berupa leverage dan financial distress terhadap variabel dependen berupa opini audit going 
concern. Pengujian hipotesis dalam penelitian ini menggunakan tingkat signifikansi 0,05 (5\%). Variabel independen dapat dinyatakan berpengaruh terhadap variabel dependen apabila memiliki tingkat signifikansi kurang dari 0,05 .

Tabel 7

Hasil Uji Regresi Logistik

\begin{tabular}{|c|c|c|c|c|c|c|c|}
\hline \multicolumn{8}{|c|}{ Variables in the Equation } \\
\hline & & B & S.E. & Wald & df & Sig. & $\operatorname{Exp}(B)$ \\
\hline \multirow{3}{*}{$\begin{array}{l}\text { Step } \\
1^{a}\end{array}$} & DAR &,- 457 & 907 & ,254 & 1 & 614 & 633 \\
\hline & Z-Score &,- 529 & 204 & 6,701 & 1 & 010 & ,589 \\
\hline & Constant & ,513 & ,778 &, 435 & 1 & ,509 & 1,671 \\
\hline
\end{tabular}

a. Variable(s) entered on step 1: Debt to Asset Ratio, Z-Score.

Sumber: Hasil Pengolahan Data (2019)

Persamaan regresi yang ditransformasikan adalah sebagai berikut:

$$
\operatorname{Ln} \frac{P}{1-P}=0,513-0,457 \mathrm{DAR}-0,529 \mathrm{ZSc} \text { ore }+\varepsilon
$$

Tabel 7 memperlihatkan bahwa leverage yang diproksikan dengan Debt to Asset Ratio (DAR) memiliki koefisien senilai 0,457 dengan tingkat signifikansi 0,614 atau > 0,05 . Hasil tersebut berarti leverage tidak berpengaruh terhadap opini audit going concern yang berarti $\mathrm{H}_{1}$ ditolak.

Financial distress yang diproksikan dengan model Altman Z-Score original memiliki koefisien senilai $-0,529$ dengan tingkat signifikansi 0,010 atau < 0,05. Hasil yang diperoleh menunjukkan bahwa financial distress berpengaruh negatif terhadap opini audit going concern, yang berarti $\mathrm{H}_{2}$ diterima.

\section{Pengaruh Leverage terhadap Opini Audit Going Concern}

Hasil yang diperoleh berdasarkan uji regresi logistik adalah leverage yang diproksikan dengan Debt to Asset Ratio (DAR) memiliki koefisien senilai $-0,457$ dengan tingkat signifikansi 0,614 atau >0,05. Hasil tersebut mengindikasikan bahwa leverage tidak berpengaruh terhadap opini audit going concern, atau $\mathrm{H}_{1}$ ditolak.
Hasil yang diperoleh mengindikasikan bahwa dalam pemberian opini going concern, auditor tidak hanya mempertimbangkan total utang yang digunakan untuk membiayai perusahaan. Tingginya nilai leverage tidak menjadi alasan utama bagi perusahaan dalam perolehan opini going concern, karena dalam pemberian opini going concern auditor tidak hanya memandang utang yang membiayai aset perusahaan melainkan kinerja perusahaan secara keseluruhan.

Utang diperlukan perusahaan untuk menjalankan kegiatan operasionalnya. Perusahaan-perusahaan sektor pertambangan mampu menutupi tingkat leverage-nya yang tinggi dengan pengelolaan aset yang baik, sehingga kemampuan perusahaan dalam melunasi utang tidak menjadi faktor yang menentukan penerimaan opini going concern. Rahman (2019) mengemukakan bahwa utang yang besar belum tentu mengindikasikan membuat kinerja perusahaan buruk.

Hasil penelitian ini bertentangan dengan penelitian sebelumnya yang dilakukan oleh Santoso dan Wiyono (2013), Aryantika dan Rasmini (2015), Lie, et al (2016), serta Anita (2017) yang menyimpulkan bahwa leverage yang diproksikan debt to asset ratio berpengaruh positif terhadap penerimaan opini audit going concern.

\section{Pengaruh Financial Distress terhadap Opini Audit Going Concern}

Hasil pengujian regresi logistik yaitu financial distress memiliki koefisien senilai 0,529 dengan tingkat signifikansi 0,010 atau < 0,05 . Hasil yang diperoleh menunjukkan bahwa financial distress memiliki pengaruh negatif terhadap opini audit going concern, yang berarti $\mathrm{H}_{2}$ diterima.

Financial distress adalah masalah keuangan yang perusahaan alami sebelum perusahaan tersebut mengalami kebangkrutan atau likuidasi. Financial distress dapat diukur menggunakan Z-Score. Semakin tinggi Z-Score yang diperoleh perusahaan atau semakin baik kondisi keuangan perusahaan, maka kelangsungan usaha perusahaan tersebut tidak diragukan lagi. Apabila perusahaan memiliki kondisi keuangan yang baik, maka kemungkinan perusahaan memperoleh opini going concern menjadi kecil. Kesumojati et al 
(2017) mengemukakan bahwa perusahaan yang tidak mengalami masalah keuangan yang serius, tidak mengalami masalah likuiditas, serta memiliki working capital yang cukup akan jauh dari kemungkinan memperoleh opini going concern.

Hasil penelitian ini sejalan dengan penelitian yang dilakukan oleh Muhamadiyah (2013), Ibrahim dan Raharja (2014), Yuliyani dan Erawati (2017), Rahim (2017), serta Jamaluddin (2018) yang menyimpulkan bahwa financial distress yang diproksikan model prediksi kebangkrutan Altman Z-Score berpengaruh negatif terhadap penerimaan opini going concern.

\section{Kesimpulan}

Leverage yang diproksikan menggunakan Debt to Asset Ratio (DAR) tidak berpengaruh terhadap opini audit going concern. Auditor tidak hanya mempertimbangkan total utang yang digunakan untuk membiayai perusahaan saat memberikan opini audit going concern. Nilai leverage yang tinggi tidak menjadi tolok ukur perusahaan dalam perolehan opini audit going concern. Auditor menilai kinerja perusahaan secara keseluruhan sebelum memberikan opini audit going concern, tidak hanya melihat leverage perusahaan. Financial Distress yang diproksikan menggunakan model Altman ZScore original berpengaruh negatif terhadap opini audit going concern. Semakin tinggi nilai $Z$-Score yang perusahaan peroleh mencerminkan kondisi keuangan perusahaan yang semakin baik, sehingga kelangsungan usaha perusahaan tersebut tidak diragukan lagi. Perusahaan dengan kondisi keuangan yang baik memiliki kemungkinan sangat kecil untuk memperoleh opini audit going concern.

\section{Daftar Pustaka}

Aliya A. (2017). Tiga Perusahaan 'Ditendang' dari Bursa, Salah Satunya Berau Coal. (https://finance.detik.com/bursa-danvalas/d-3693242/tiga-perusahaanditendang-dari-bursa-salah-satunyaberau-coal). Diakses pada 20 Juli 2018.

Anita WF. (2017). Analisis Faktor-Faktor yang Mempengaruhi Opini Audit Going Concern pada Perusahaan Manufaktur yang Terdaftar di Bursa Efek Indonesia. Jurnal Riset Keuangan dan Akuntansi. 3 (2), Agustus 2017.

Aryantika NPP, Rasmini NK. (2015). Profitabilitas, Leverage, Prior Opinion dan Kompetensi Auditor Pada Opini Audit Going Concern. E-Jurnal Akuntasi Universitas Udayana. 11 (2), 2015.

Bursa Efek Indonesia. (http://www.idx.co.id). Diakses pada 22 Maret 2019.

Gitman LJ, Zutter CJ. (2012). Principles of Managerial Finance. 13th Edition. USA: Prentice Hall.

Ibrahim SP, Raharja. (2014). Pengaruh Audit Lag, Rasio Leverage, Rasio Arus Kas, Opini Audit Tahun Sebelumnya dan Financial Distress Terhadap Penerimaan Opini Going Concern (Studi pada Perusahaan Manufaktur yang Terdaftar di BEI Tahun 2009-2012). Diponegoro Journal of Accounting. 3 (3), 2014, hal. 1-11.

Institut Akuntan Publik Indonesia. (2013). Standar Profesional Akuntan Publik (SA) 570. Jakarta: Salemba Empat.

Jamaluddin M. (2018). The Effect of Financial Distress and Disclosure on Going Concern Opinion of The Banking Company Listing in Indonesian Stock Exchange. International Journal of Scientific Research and Management (IJSRM). 6 (1), 2018.

Lie C, Wardani RP, Pikir TW. (2016). Pengaruh Likuiditas, Solvabilitas, Profitabilitas, dan Rencana Manajemen terhadap Opini Audit Going Concern (Studi Empiris Perusahaan Manufaktur di BEI). Berkala Akuntansi dan Keuangan Indonesia. 1 (2), 2016.

Lin B, Lee ZH, Gibbs LG. (2008). Operational Restructuring: Reviving an Ailing Business. Management Decision. 46 (4), pp. 539-552. 
Muhamadiyah F. (2013). Opini Audit Going Concern: Kajian Berdasarkan Model Prediksi Kebangkrutan, Pertumbuhan Perusahaan, Leverage dan Reputasi Kantor Akuntan Publik. Media Riset Akuntansi, Auditing \& Informasi. 13 (1), April 2013.

Murni Y, Majid E. (2017). Faktor-faktor yang Mempengaruhi Penerimaan Opini Audit Going Concern Pada Perusahaan Manufaktur di Indonesia. Dalam Konferensi Ilmiah Akuntansi IV, 2-3 Maret 2017.

Platt HD, Platt MB. (2006). Understanding Differences Between Financial Distress and Bankruptcy. Review of Applied Economic. 2 (2), 2006.

PricewaterhouseCoopers. (2015). PWC: Tahun 2015 Sebagai Tahun Terburuk Bagi Sektor Pertambangan.

(www.pwc.com/id/en/media-

centre/pwc-innews/2016/indonesian/pwc---tahun2015-sebagai-tahun-terburuk-bagisektor-pertambangan.html). Diakses pada 21 Maret 2018.

Rahim S. (2017). Pengaruh Kondisi Keuangan Perusahaan, Kualitas Audit dan Opinion Shopping Terhadap Penerimaan Opini Going Concern. Jurnal Ilmiah Akuntansi dan Bisnis. 11 (2), Juli 2016.

Rahman, H. A. (2019). Dampak Strategi Diversifikasi dan Leverage terhadap Kinerja Keuangan Klub-klub Sepak Bola di Liga Inggris. Jurnal Online Insan Akuntan, 4(1), 29-42.

Santoso EB, Wiyono IY. (2013). Pengaruh Reputasi Auditor, Prediksi Kebangkrutan, Disclosure dan Leverage Terhadap Penerimaan Opini Audit Going Concern. Akrual, 4 (2), 2013.

Yuliyani NMA, Erawati MA. (2017). Pengaruh Financial Distress, Profitabilitas, Leverage dan Likuiditas pada Opini Audit Going Concern. E-Jurnal
Akuntansi Universitas Udayana. 19 (2), Mei 2017. 